\title{
Fabrication of Ferroelectric Lead Iron Tungstate Ceramics Via a Two-Stage Solid-State Reaction
}

\author{
Chung-Hsin Lu* \& Yeak-Chong Wong \\ Department of Chemical Engineering, National Taiwan University, Taipei, Taiwan
}

(Received 26 Septcmber 1994; accepted 16 January 1995)

\begin{abstract}
Ferroelectric $\mathrm{Pb}\left(\mathrm{Fe}_{2 / 3} \mathrm{~W}_{1 / 3}\right) \mathrm{O}_{3}$ was synthesized via a new two-stage solid-state reaction discussed in the present study. This method utilized $\mathrm{Fe}_{2} \mathrm{WO}_{6}$ prepared at the first-stage which subsequently reacted with a stoichiometric amount of $\mathrm{PbO}$ at the second stage. This process efficiently suppressed the formation of lead tungstates and liquid phases; in addition, pyrochlore phase was formed as the only intermediate compound. A substantial amount of pyrochlore phase was converted to $\mathrm{Pb}\left(\mathrm{Fe}_{2 / 3} \mathrm{~W}_{1 / 3}\right) \mathrm{O}_{3}$ at around $710^{\circ} \mathrm{C}$ associated with an endothermic reaction. On heating up to $750^{\circ} \mathrm{C}$ over $99 \%$ perovskite $\mathrm{Pb}\left(\mathrm{Fe}_{2 / 3} \mathrm{~W}_{1 / 3}\right) \mathrm{O}_{3}$ was formed, and this formation became complete at $840^{\circ} \mathrm{C}$. Compared with the conventional solid-state reaction, this process not only simplified the formation process, but also reduced the formation temperature of $\mathrm{Pb}\left(\mathrm{Fe}_{2 / 3} \mathrm{~W}_{1 / 3}\right) \mathrm{O}_{3}$. The crystal structure of $\mathrm{Fe}_{2} \mathrm{WO}_{6}$ did not significantly influence the formation mechanism; whereas, the morphology of $\mathrm{Pb}\left(\mathrm{Fe}_{2 / 3} \mathrm{~W}_{1 / 3}\right) \mathrm{O}_{3}$ was markedly affected by the grain size of $\mathrm{Fe}_{2} \mathrm{WO}_{6}$. By using this process, pure $\mathrm{Pb}\left(\mathrm{Fe}_{2 / 3} \mathrm{~W}_{1 / 3}\right) \mathrm{O}_{3}$ with a submicron microstructure was successfully fabricated.
\end{abstract}

\section{INTRODUCTION}

Lead iron tungstate $\mathrm{Pb}\left(\mathrm{Fe}_{2 / 3} \mathrm{~W}_{1 / 3}\right) \mathrm{O}_{3}$, a relaxor ferroelectric compound with a perovskite structure, has been widely utilized in the fabrication of multilayer capacitors with $\mathrm{Ag} / \mathrm{Pd}$ internal electrodes due to its characteristics of a high dielectric permittivity and low-temperature sinterability. ${ }^{1}$ For the sake of controlling calcination conditions, the conventional solid-state reaction of $\mathrm{Pb}\left(\mathrm{Fe}_{23} \mathrm{~W}_{1 / 3}\right) \mathrm{O}_{3}$ has been thoroughly investigated..$^{2-6}$ In the reaction process, a substantial amount of lead tungstates and pyrochlore phase are produced; in addition, two liquid phases are formulated at 690 and $860^{\circ} \mathrm{C}$, respectively. ${ }^{5,6}$ The formation of these liquid phases is involved with the reaction between several unknown phases. ${ }^{5,6}$ The progression of the formation of these intermediate compounds causes the complexity in the reaction process, hence

*To whom correspomdenee should be addressed. resulting in the difficulty in fabricating pure $\mathrm{Pb}\left(\mathrm{Fe}_{2 / 3} \mathrm{~W}_{1 / 3}\right) \mathrm{O}_{3}$ compound.

Various kinds of solution methods have been used for alternating the reaction routes so as to yield pure $\mathrm{Pb}\left(\mathrm{Fe}_{2 / 3} \mathrm{~W}_{1 / 3}\right) \mathrm{O}_{3}$ without parasite lead tungstates. Using a two-stage precipitation process $^{7}$ or sol-gel process ${ }^{8}$ can fabricate pure $\mathrm{Pb}\left(\mathrm{Fe}_{2 / 3} \mathrm{~W}_{1 / 3}\right) \mathrm{O}_{3}$ because both the homogeneity and reactivity of reactants are significantly improved in the starting materials. Despite the fact that the goal of obtaining pure $\mathrm{Pb}\left(\mathrm{Fe}_{2 / 3} \mathrm{~W}_{1 / 3}\right) \mathrm{O}_{3}$ has been achieved, considering the complicated and severe operation conditions demanded by the above solution processes, an alternative method excluding the handling of solution and of moisture-sensitive materials such as alkoxides is still required. This needed to be developed considering economical factors in mass production for industry.

The two-stage solid-state reaction is a synthesis process first used by Swartz and Shrout ${ }^{9}$ in fabri413 
$\mathrm{MgO}$ is first reacted with $\mathrm{Nb}_{2} \mathrm{O}_{5}$ to produce columbite $\mathrm{MgNb}_{2} \mathrm{O}_{6}$, followed by the second reaction between the $\mathrm{MgNb}_{2} \mathrm{O}_{6}$ and $\mathrm{PbO}$. Adding $2 \%$ excess $\mathrm{PbO}$ can eliminate the presence of pyrochlore phase and produce pure $\mathrm{Pb}\left(\mathrm{Mg}_{1 / 3} \mathrm{Nb}_{2 / 3}\right) \mathrm{O}_{3}$ phase.

It is considered that the two-stage solid-state reaction can bypass the formation of intermediate compounds, e.g. lead tungstates and liquid phases formed in the conventional solid-state reaction, thereby simplifying the reaction process. Therefore, the difficulty in synthesizing a pure compound will be reduced. In this study, the following two-stage solid-reaction sequence is designed for synthesizing $\mathrm{Pb}\left(\mathrm{Fe}_{2 / 3} \mathrm{~W}_{1 / 3}\right) \mathrm{O}_{3}$ :

the first stage: $\mathrm{Fe}_{2} \mathrm{O}_{3}+\mathrm{WO}_{3} \rightarrow \mathrm{Fe}_{2} \mathrm{WO}_{6}$ and the second stage:

$$
\mathrm{Fe}_{2} \mathrm{WO}_{6}+3 \mathrm{PbO} \rightarrow \mathrm{Pb}\left(\mathrm{Fe}_{2 / 3} \mathrm{~W}_{1 / 3}\right) \mathrm{O}_{3}
$$

In the above process only oxides of solid-powder form are utilized and no solution is required to be treated. The reaction mechanism and microstructural evolution in the obtained powders are investigated in this work.

\section{EXPERIMENTAL}

At the first stage, $\mathrm{Fe}_{2} \mathrm{O}_{3}(99+\%$, Aldrich Chem. Co. Inc., USA) and $\mathrm{WO}_{3}(99+\%$, Aldrich Chem. Co. Inc., USA) were used as starting materials for synthesizing $\mathrm{Fe}_{2} \mathrm{WO}_{6}$. Oxides were ball-milled in a plastic jar with ethanol for $48 \mathrm{~h}$ using zirconium oxide balls. Then the mixed slurry was dried at about $70^{\circ} \mathrm{C}$ by using a rotary evaporator. The dried powder was uniaxially cold-pressed into pellets by applying pressure of $196 \mathrm{MPa}$ and heated at $700-1100^{\circ} \mathrm{C}$ for $2-48 \mathrm{~h}$. The pressed pellets were placed in an alumina crucible and buried in a $\mathrm{WO}_{3}$ powder-bed to prevent the volatilization of $\mathrm{WO}_{3}$. After calcination, the surface of pellets was stripped off to eliminate the attached $\mathrm{WO}_{3}$ powder which would influence the stoichiometric ratio of products.

At the second stage, $\mathrm{PbO}$ (99.9\%, Aldrich Chem. Co. Inc., USA) was mixed with prepared $\mathrm{Fe}_{2} \mathrm{WO}_{6}$ so as to fabricate $\mathrm{Pb}\left(\mathrm{Fe}_{2 / 3} \mathrm{~W}_{1 / 3}\right) \mathrm{O}_{3}$ perovskite. The mixing, drying, and pressing procedures were the same as described above. The mixed $\mathrm{Fe}_{2} \mathrm{WO}_{6}$ and $\mathrm{Pb}\left(\mathrm{Fe}_{2 / 3} \mathrm{~W}_{1 / 3}\right) \mathrm{O}_{3}$ precursors were analyzed by differential thermal analysis (DTA) and thermogravimetry (TGA) using $\mathrm{Al}_{2} \mathrm{O}_{3}$ as standard. DTA was carried out in flowing air at a rate of $80 \mathrm{cc} / \mathrm{min}$ with heating and cooling rates of $5^{\circ} \mathrm{C} / \mathrm{min}$. The mixed $\mathrm{Pb}\left(\mathrm{Fe}_{2 / 3} \mathrm{~W}_{1 / 3}\right) \mathrm{O}_{3}$ precursor was heated to specific temperatures in a furnace and quenched in air to examine the reaction mechanism and microstructure variation. X-ray powder diffraction (XRD) was performed in order to analyze the for- mation of resultant compounds. The applied voltage and current were $40 \mathrm{kV}$ and $30 \mathrm{~mA}$, respectively, using a $\mathrm{Cu}$ tube with a $\mathrm{Ni}$ filter. Scanning elcctron microscopy (SEM) was utilized for observing microstructural variation in heated specimens.

\section{RESULTS AND DISCUSSION}

\section{Fabrication of $\mathrm{Fe}_{2} \mathrm{WO}_{6}$}

Figure 1 (a) and (b) depicts the DTA and TGA curves of the thermal and weight variation for the mixed materials of $\mathrm{Fe}_{2} \mathrm{WO}_{6}$. No exothermic or endothermic peaks in DTA can be observed over the whole measured temperature range; however, the base-line of DTA was gradually shifted to the exothermic side from above $800^{\circ} \mathrm{C}$. This result implies that the formation of $\mathrm{Fe}_{2} \mathrm{WO}_{6}$ was sluggish and may initiate from around $800^{\circ} \mathrm{C}$. Notably, two stages of weight loss occurred in the TGA curve. The weight loss at the first stage was about $2 \%$, at a temperature lower than $400^{\circ} \mathrm{C}$. It

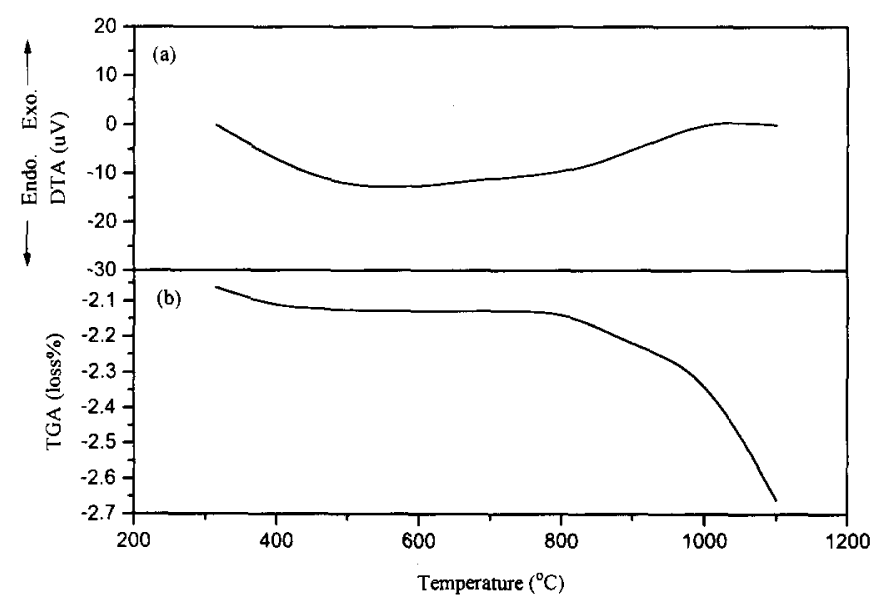

Fig. 1. (a) Differential thermal analysis, and (b) thermogravimetric analysis of the mixture of $\mathrm{Fe}_{2} \mathrm{O}_{3}$ and $\mathrm{WO}_{3}$.

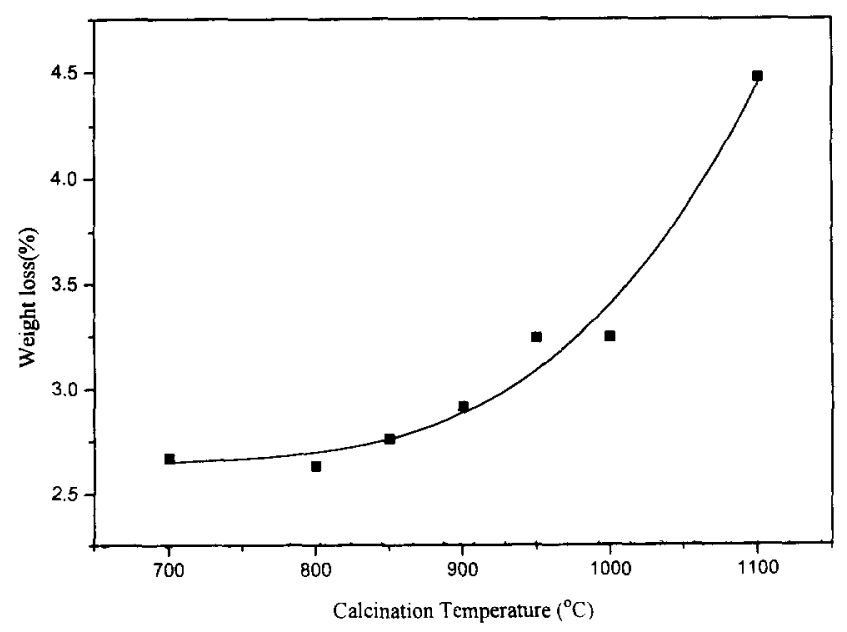

Fig. 2. Weight loss of the mixture of $\mathrm{Fe}_{2} \mathrm{O}_{3}$ and $\mathrm{WO}_{3}$ heated at various temperatures for $2 \mathrm{~h}$. 


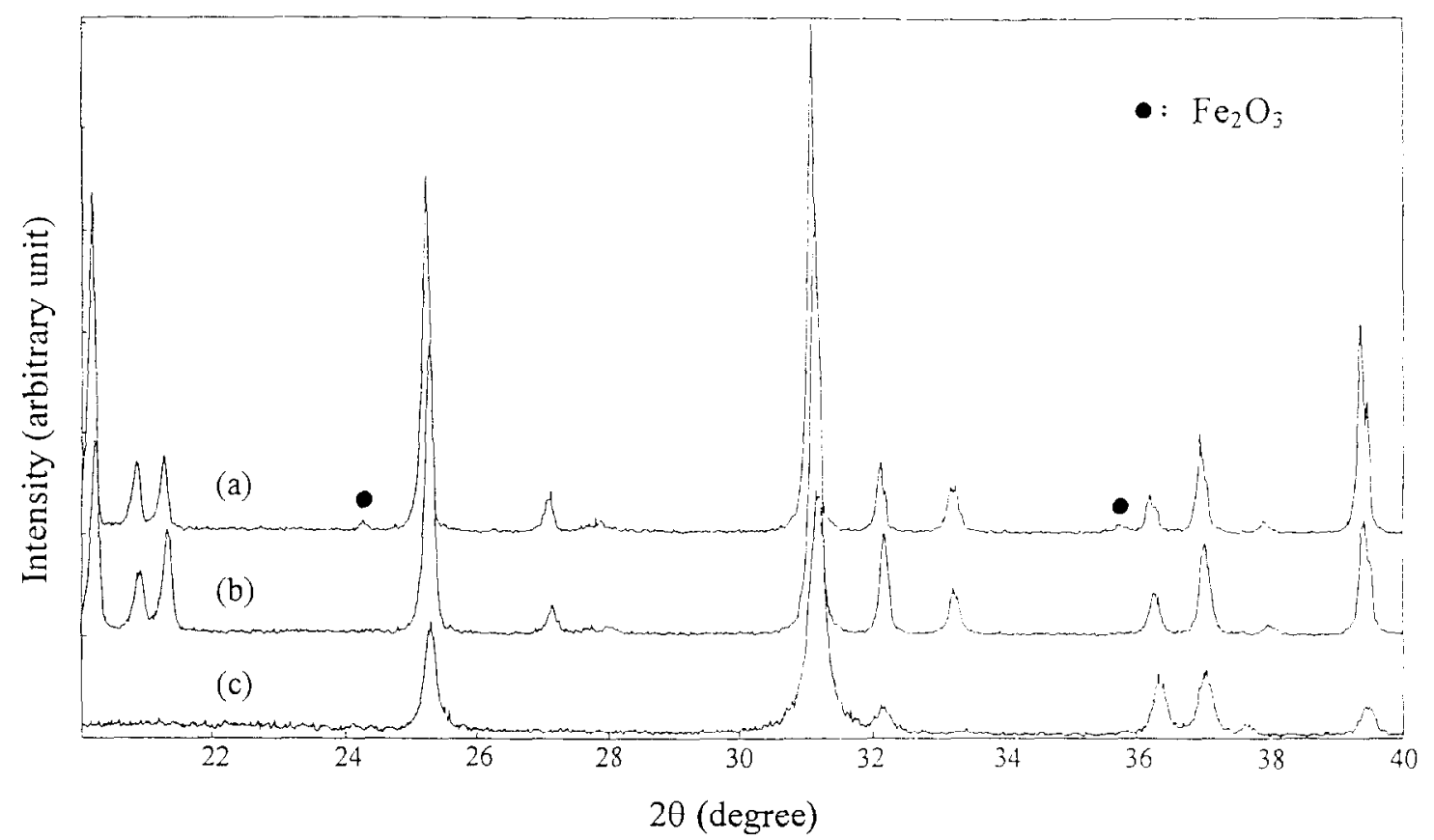

Fig. 3. X-ray diffraction patterns of (a) form $2-\mathrm{Fe}_{2} \mathrm{WO}_{6}$ with residual $\mathrm{Fe}_{2} \mathrm{O}_{3}$ formed via being calcined at $1100^{\circ} \mathrm{C}$ for $6 \mathrm{~h}$, (b) form $2-\mathrm{Fe}_{2} \mathrm{WO}_{6}$ formed via being heated at $1100^{\circ} \mathrm{C}$ for $6 \mathrm{~h}$ with a $\mathrm{WO}_{3}$ powder-bed, (c) form $1-\mathrm{Fe}_{2} \mathrm{WO}_{6}$ formed via being heated at $800^{\circ} \mathrm{C}$ for $6 \mathrm{~h}$ and $850^{\circ} \mathrm{C}$ for $8 \mathrm{~h}$ with a WO 3 powder-bed.

was caused by the combustion of residual resin introduced during ball-milling. Above $800^{\circ} \mathrm{C}$, the weight loss markedly increased with the increase in temperature. The volatilization of $\mathrm{WO}_{3}$ is believed to be responsible for the weight loss at the second stage. Prepared pellets were calcined from 700 to $1100^{\circ} \mathrm{C}$ for $2 \mathrm{~h}$ so as to further examine the behavior of weight loss at elevated temperatures. Similar results can be seen in Fig. 2. From this figure, it is evident that the weight loss was substantially increased from about $800^{\circ} \mathrm{C}$.

The volatilization of $\mathrm{WO}_{3}$ during heating will leave residual $\mathrm{Fe}_{2} \mathrm{O}_{3}$ in the final products which directly influences the stoichiometric ratio of cations in $\mathrm{Fe}_{2} \mathrm{WO}_{6}$. For the sake of preventing volatilization of $\mathrm{WO}_{3}$, in the following experiments, pellets were buried in a $\mathrm{WO}_{3}$ powder-bed during the heating process so as to suppress the loss of $\mathrm{WO}_{3}$. The effect of the $\mathrm{WO}_{3}$ powder-bed on resultant products is shown in Fig. 3. Pure $\mathrm{Fe}_{2} \mathrm{WO}_{6}$ can be fabricated by means of introducing $\mathrm{WO}_{3}$ powder-bed (Fig. 3(b) and (c)); on the other hand, residual $\mathrm{Fe}_{2} \mathrm{O}_{3}$ was present in products when no powder-bed was utilized (see Fig. 3(a)).

Two different forms of $\mathrm{Fe}_{2} \mathrm{WO}_{6}$ can be synthesized by varying the calcination temperature and dwelling time. Figure 3(b) and (c) illustrates the XRD patterns for form 2 and form 1 of $\mathrm{Fe}_{2} \mathrm{WO}_{6}$. The variation of the crystal structure of $\mathrm{Fe}_{2} \mathrm{WO}_{6}$ in terms of calcination temperature and time is depicted in Fig. 4. Form 1 was formed at low temperatures with a columbite structure. Form 1 of
$\mathrm{Fe}_{2} \mathrm{WO}_{6}$ will undergo a monotropic phase-transformation at higher temperatures to produce form $2 \mathrm{Fe}_{2} \mathrm{WO}_{6}$, and to alter the structure from columbite to $\alpha$-PbO type. ${ }^{10,11}$ As shown in Fig. 4, no reaction occurred between $\mathrm{Fe}_{2} \mathrm{O}_{3}$ and $\mathrm{WO}_{3}$ at $700^{\circ} \mathrm{C}$. Form 1 of $\mathrm{Fe}_{2} \mathrm{WO}_{6}$ began to generate at $800^{\circ} \mathrm{C}$ but not completely. Prolonging the dwelling time to $8 \mathrm{~h}$ at $800^{\circ} \mathrm{C}$ still could not yield pure form 1. However, when the temperature was raised to $850^{\circ} \mathrm{C}$ even only for $2 \mathrm{~h}$, all reactants became form 1 of $\mathrm{Fe}_{2} \mathrm{WO}_{6}$. Heating at $900^{\circ} \mathrm{C}$ for $8 \mathrm{~h}$ can also obtain form 1; meanwhile, prolonging the dwelling time to $48 \mathrm{~h}$ at the same temperature can yield form 2 . On heating at $950^{\circ} \mathrm{C}$ over $2 \mathrm{~h}$, the final product turned out to be form 2 of $\mathrm{Fe}_{2} \mathrm{WO}_{6}$. It seems that the phase transformation

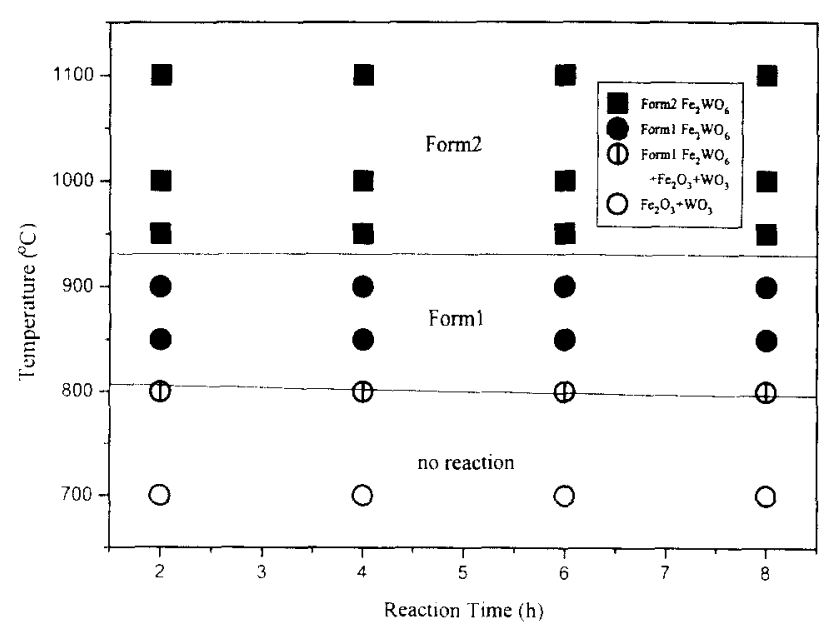

Fig. 4. Formation diagram of form 1 and form 2 of $\mathrm{Fe}_{2} \mathrm{WO}_{6}$. 
of $\mathrm{Fe}_{2} \mathrm{WO}_{6}$ from form 1 to form 2 took place at temperatures between 900 and $950^{\circ} \mathrm{C}$.

In the following experiments, form 1 synthesized via $800^{\circ} \mathrm{C}-2 \mathrm{~h}$ and subsequent $850^{\circ} \mathrm{C}-8 \mathrm{~h}$ heating, and form 2 synthesized at $900^{\circ} \mathrm{C}$ for $48 \mathrm{~h}$, were utilized as the starting materials to react with a stoichiometric amount of $\mathrm{PbO}$ at the second stage of reaction. The raw materials of $\mathrm{Pb}\left(\mathrm{Fe}_{2 / 3} \mathrm{~W}_{1 / 3}\right) \mathrm{O}_{3}$, prepared via form 1 and form 2 of $\mathrm{Fe}_{2} \mathrm{WO}_{6}$, are denoted as PFW1 and PFW2, respectively. The microstructures of the two forms of $\mathrm{Fe}_{2} \mathrm{WO}_{6}$ used in the $\mathrm{Pb}\left(\mathrm{Fe}_{2 / 3} \mathrm{~W}_{1 / 3}\right) \mathrm{O}_{3}$ synthesis are shown in Fig. 5. No obvious difference between them can be distinguished except that form 2 had a slightly larger grain size than form 1.

\section{Formation process of $\mathrm{Pb}\left(\mathrm{Fe}_{2 / 3} \mathrm{~W}_{1 / 3}\right) \mathrm{O}_{3}$}

The DTA results for PFW1 and PFW2 were similar. The representative curves for PFW1 are illustrated in Fig. 6. During heating, only an

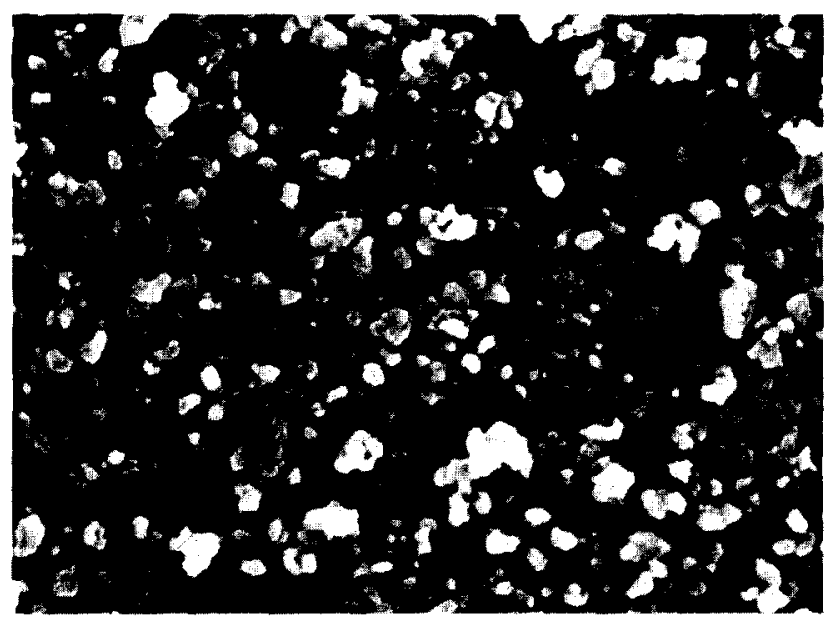

(a)

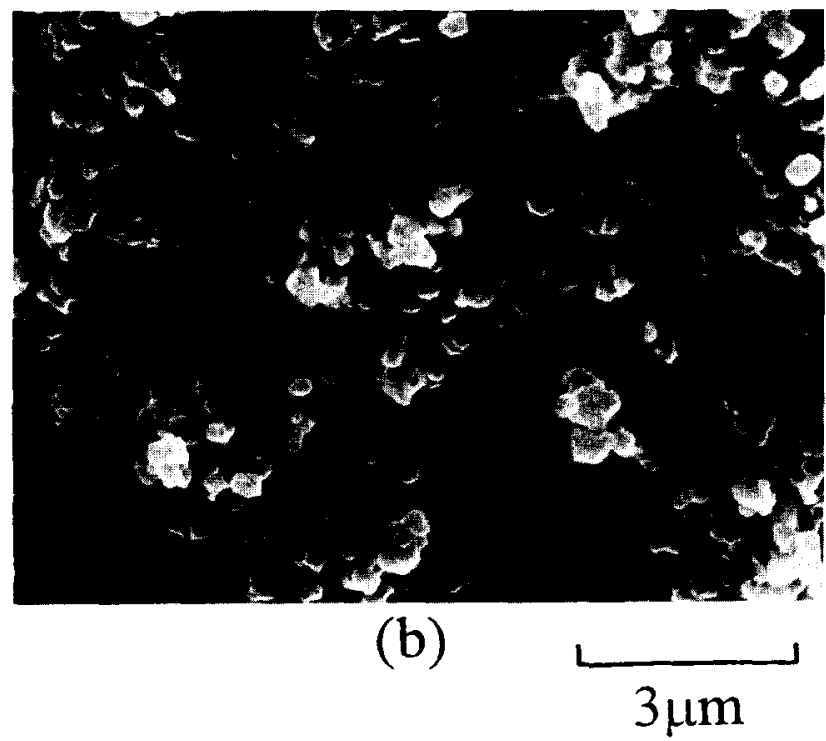

Fig. 5. Scanning electron micrographs of (a) form $1-\mathrm{Fe}_{2} \mathrm{WO}_{6}$ and (b) form $2-\mathrm{Fc}_{2} \mathrm{WO}_{6}$. endothermic peak can be observed near $710^{\circ} \mathrm{C}$. In the two cooling runs from 730 and $870^{\circ} \mathrm{C}$, respectively, no thermal variation could be found. For conventional solid-state reaction, two endothermic peaks occurred near 690 and $860^{\circ} \mathrm{C}$, respectively, corresponding to the formation of liquid phases. ${ }^{6,7}$ In contrast to the conventional solid-state reaction, the fact that no endothermic reactions occurred at 690 and $860^{\circ} \mathrm{C}$ during heating and no exothermic reactions took place in cooling indicates that no liquid phases were formed in the two-stage solid-state reaction.

The PFW1 and PFW2 samples were heated and quenched at temperatures from 400 to $870^{\circ} \mathrm{C}$, and then analyzed via XRD. The relative amount of each resultant compound present in PFW1 and PFW2 was semi-quantitatively calculated as follows:

Relative intensity of compound $i(\%)=\frac{I_{i}}{\Sigma\left(I_{i}\right)} \times 100 \%$

where $I_{i}$ is the intensity of the strongest diffraction peak for compound $i$. As shown in Fig. 7, the formation process of PFW1 was similar to that of PFW2. No lead tungstates and other unknown phases were present during reaction except pyrochlore phase appearing as the only intermediate compound. In both PFW1 and PFW2, PbO and $\mathrm{Fe}_{2} \mathrm{WO}_{6}$ concentration decreased with rising temperature and completely disappeared at $600^{\circ} \mathrm{C}$. Pyrochlore phase began to form at $400^{\circ} \mathrm{C}$ and its amount increased up to $600^{\circ} \mathrm{C}$. The formation of $\mathrm{Pb}\left(\mathrm{Fe}_{2 / 3} \mathrm{~W}_{1 / 3}\right) \mathrm{O}_{3}$ initiated from $500^{\circ} \mathrm{C}$; in addition, its content significantly increased from above $700^{\circ} \mathrm{C}$ accompanied by a corresponding reduction in pyrochlore phase. Up to $750^{\circ} \mathrm{C}$, over $99 \%$ perovskite $\mathrm{Pb}\left(\mathrm{Fe}_{2 / 3} \mathrm{~W}_{1 / 3}\right) \mathrm{O}_{3}$ can be obtained. When the temperature was raised to $840^{\circ} \mathrm{C}$, pure $\mathrm{Pb}\left(\mathrm{Fe}_{2 / 3} \mathrm{~W}_{1 / 3}\right) \mathrm{O}_{3}$ was entirely yielded. According to the DTA (Fig. 6) and XRD (Fig. 7) results, it was

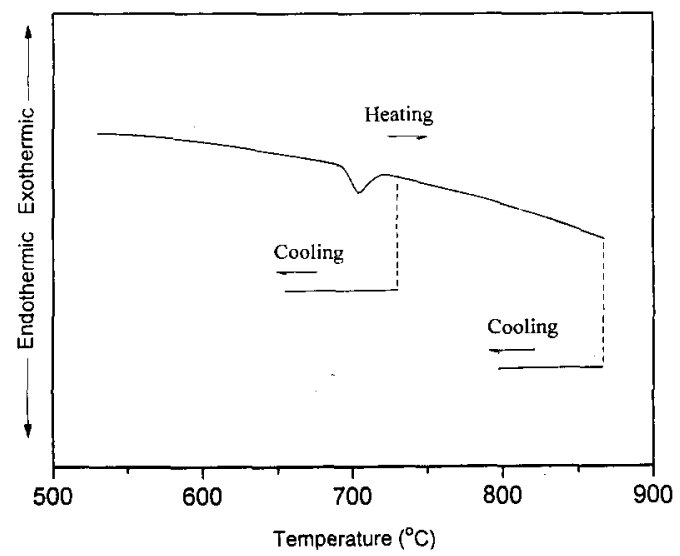

Fig. 6. Differential thermal analysis of the mixture of $\mathrm{PbO}$ and $\mathrm{Fe}_{2} \mathrm{WO}_{6}$. 


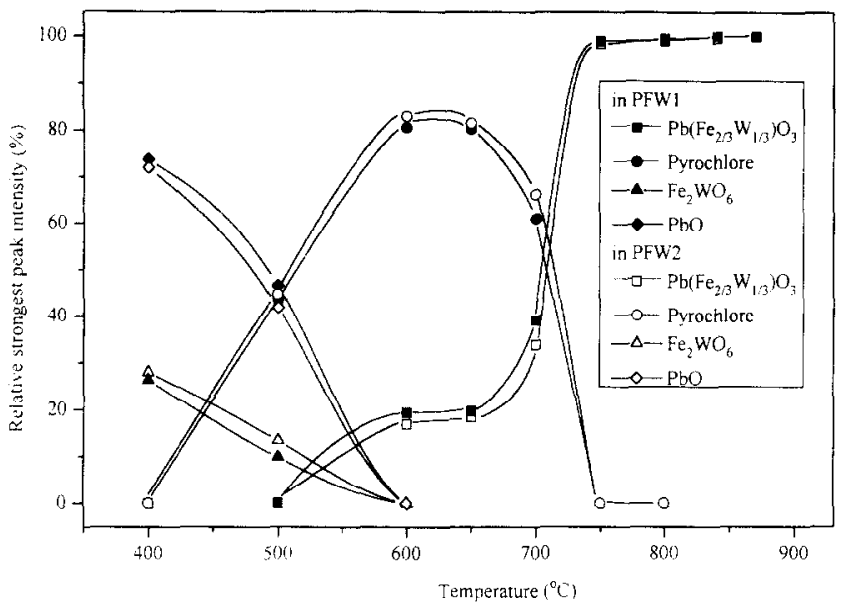

Fig. 7. Content of resultant compounds in PFWI and PFW2 specimens.

evident that the endothermic reaction at around $710^{\circ} \mathrm{C}$ could be ascribed to the reaction of pyrochlore phase converting to $\mathrm{Pb}\left(\mathrm{Fe}_{2 / 3} \mathrm{~W}_{1 / 3}\right) \mathrm{O}_{3}$.

Comparing the formation process of PFW1 to that of PFW2, it is noted that the amount of pyrochlore phase in PFW1 was slightly less than that in PFW2 at a low temperature range; nevertheless, the amount of $\mathrm{Pb}\left(\mathrm{Fe}_{2 / 3} \mathrm{~W}_{1 / 3}\right) \mathrm{O}_{3}$ in PFW1 was slightly greater than that in PFW2 at elevated temperatures. These results imply that when the amount of pyrochlore phase is reduced at low temperatures, the formation of $\mathrm{Pb}\left(\mathrm{Fe}_{2 / 3} \mathrm{~W}_{1 / 3}\right) \mathrm{O}_{3}$ would be facilitated at high temperatures. On the other hand, the crystal structure of $\mathrm{Fe}_{2} \mathrm{WO}_{6}$ did not seem to obviously influence the formation process of $\mathrm{Pb}\left(\mathrm{Fe}_{2 / 3} \mathrm{~W}_{1 / 3}\right) \mathrm{O}_{3}$.

\section{Microstructural evolution}

Figures 8 and 9 show the microstructure of PFW1 and PFW2 specimens quenched at 600,750 and $870^{\circ} \mathrm{C}$, respectively. Comparable microstructure evolution was observed in PFW1 and PFW2. At $600^{\circ} \mathrm{C}$, the major compound present in specimens was pyrochlore phase which had a grain size around $0 \cdot 1-0.2 \mu \mathrm{m}$. When the temperature was raised to $750^{\circ} \mathrm{C}$, most of the pyrochlore phase converted to perovskite $\mathrm{Pb}\left(\mathrm{Fe}_{2 / 3} \mathrm{~W}_{1 / 3}\right) \mathrm{O}_{3}$. At this temperature the grain size of $\mathrm{Pb}\left(\mathrm{Fe}_{2 / 3} \mathrm{~W}_{1 / 3}\right) \mathrm{O}_{3}$ was approximately $0.2-0.3 \mu \mathrm{m}$. Up to $870^{\circ} \mathrm{C}$, the grain-size of $\mathrm{Pb}\left(\mathrm{Fe}_{2 / 3} \mathrm{~W}_{1 / 3}\right) \mathrm{O}_{3}$ still lay in the submicron range of $0.5-0.6 \mu \mathrm{m}$. The grain of $\mathrm{Pb}\left(\mathrm{Fe}_{2 / 3} \mathrm{~W}_{1 / 3}\right) \mathrm{O}_{3}$ prepared by the two-stage solidstate reaction turned out to be the finest among all other synthesis processes. ${ }^{6-8}$

The grain-size effect of form $2-\mathrm{Fe}_{2} \mathrm{WO}_{6}$ on the formation of $\mathrm{Pb}\left(\mathrm{Fe}_{2 / 3} \mathrm{~W}_{1 / 3}\right) \mathrm{O}_{3}$ was also cxamined. The calcination condition for $\mathrm{Fe}_{2} \mathrm{WO}_{6}$ was increased to $950^{\circ} \mathrm{C}$ for $8 \mathrm{~h}$. The microstructures of

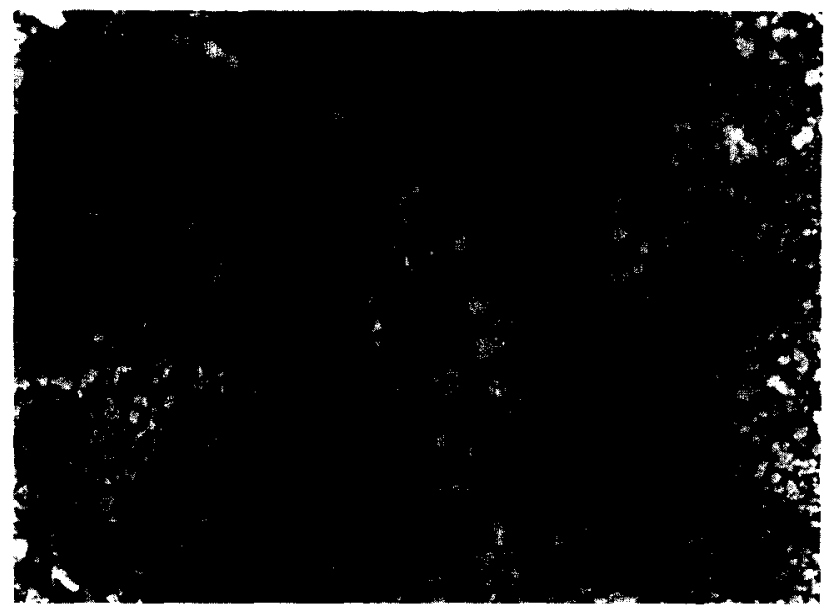

(a)

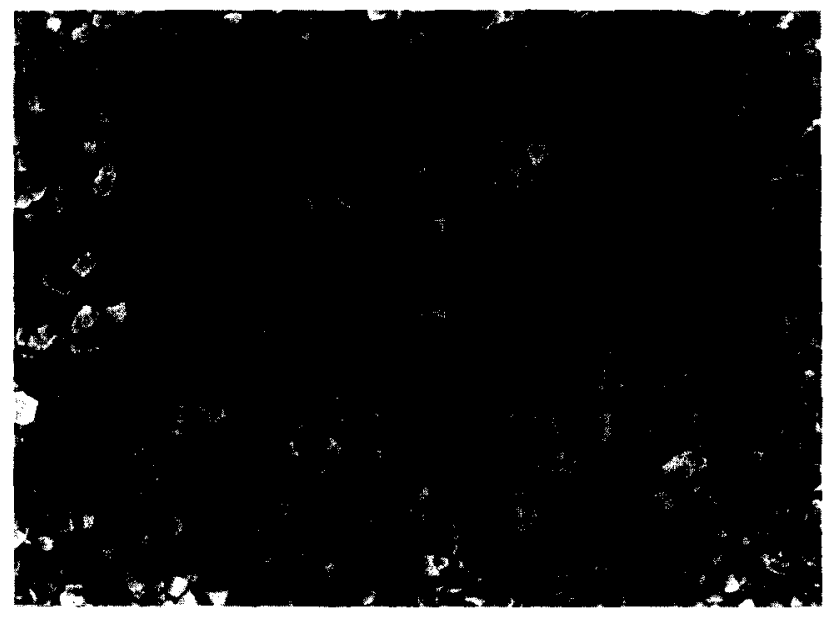

(b)

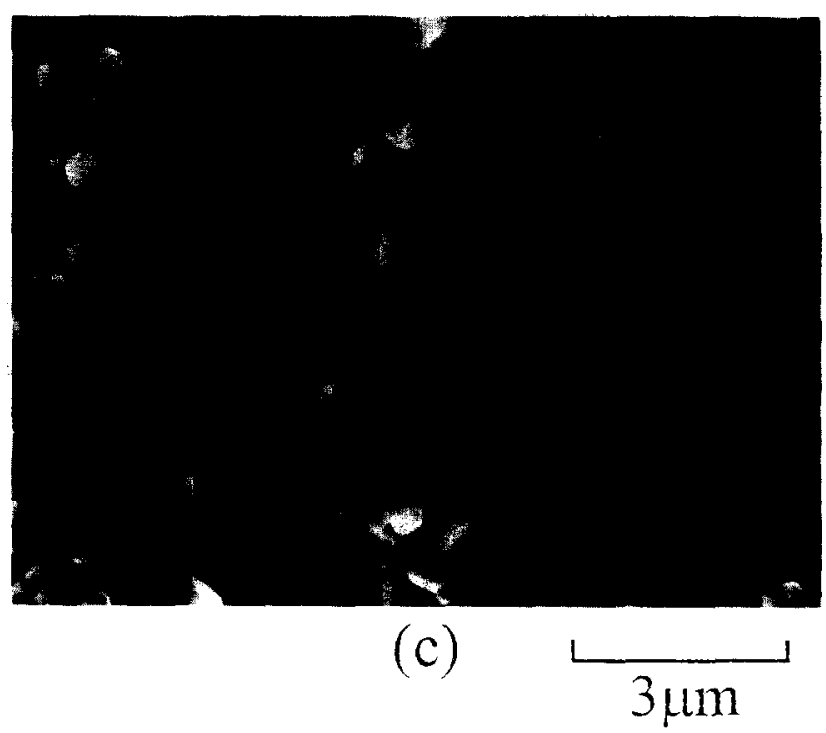

Fig. 8. Scanning electron micrographs for PFW1 quenched at (a) $600^{\circ} \mathrm{C}$, (b) $750^{\circ} \mathrm{C}$ and (c) $870^{\circ} \mathrm{C}$.

$\mathrm{Fe}_{2} \mathrm{WO}_{6}$ and derived $\mathrm{Pb}\left(\mathrm{Fe}_{2 / 3} \mathrm{~W}_{1 / 3}\right) \mathrm{O}_{3}$ are shown in Fig. 10(a) and (b). It was found that both $\mathrm{Fe}_{2} \mathrm{WO}_{6}$ and $\mathrm{Pb}\left(\mathrm{Fe}_{2 / 3} \mathrm{~W}_{1 / 3}\right) \mathrm{O}_{3}$ had larger grain size than those shown in Figs 5(b) and 9(c). This indicates that controlling the grain size of $\mathrm{Fe}_{2} \mathrm{WO}_{6}$ can effectively alter the grain size of $\mathrm{Pb}\left(\mathrm{Fe}_{2 / 3} \mathrm{~W}_{1 / 3}\right) \mathrm{O}_{3}$. 


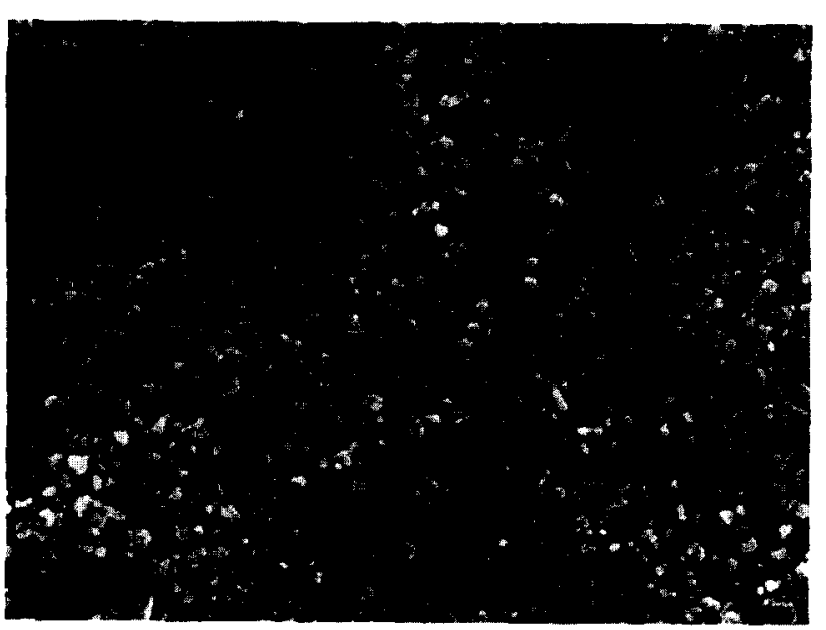

(a)

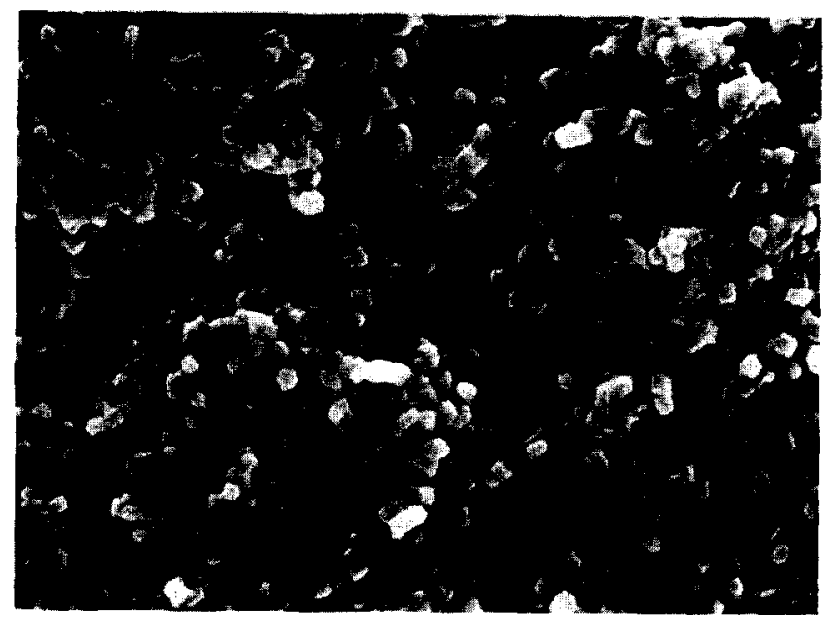

(b)

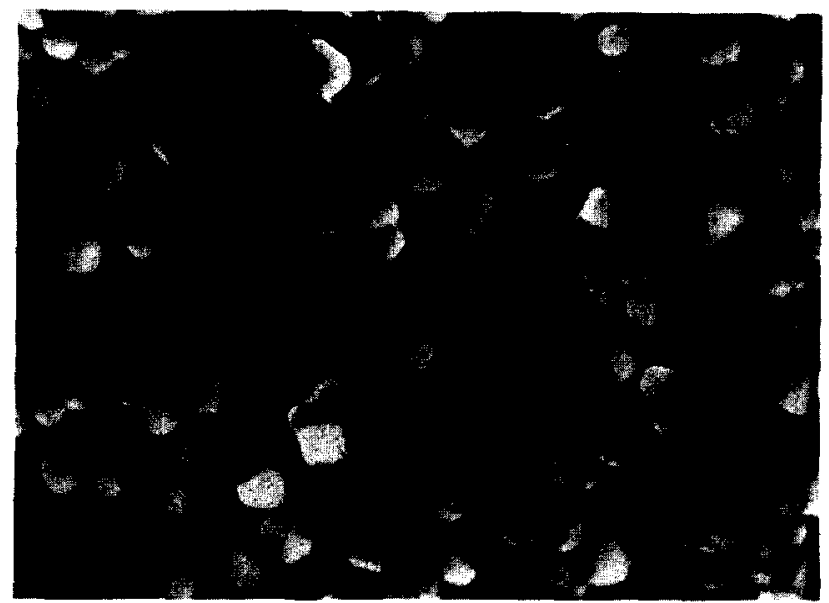

(c)

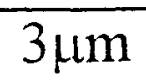

Fig. 9. Scanning electron micrographs for PFW2 quenched at (a) $600^{\circ} \mathrm{C}$, (b) $750^{\circ} \mathrm{C}$ and (c) $870^{\circ} \mathrm{C}$.

In the reaction between $\mathrm{PbO}$ and $\mathrm{Fe}_{2} \mathrm{WO}_{6}, \mathrm{PbO}$ is considered to unidirectionally diffuse into $\mathrm{Fe}_{2} \mathrm{WO}_{6}$ in generating the pyrochlore phase. Hence $\mathrm{Fe}_{2} \mathrm{WO}_{6}$ determines the morphology of the pyrochlore phase, and the pyrochlore phase will subsequently influence the morphology of $\mathrm{Pb}\left(\mathrm{Fe}_{2 / 3} \mathrm{~W}_{1 / 3}\right) \mathrm{O}_{3}$.

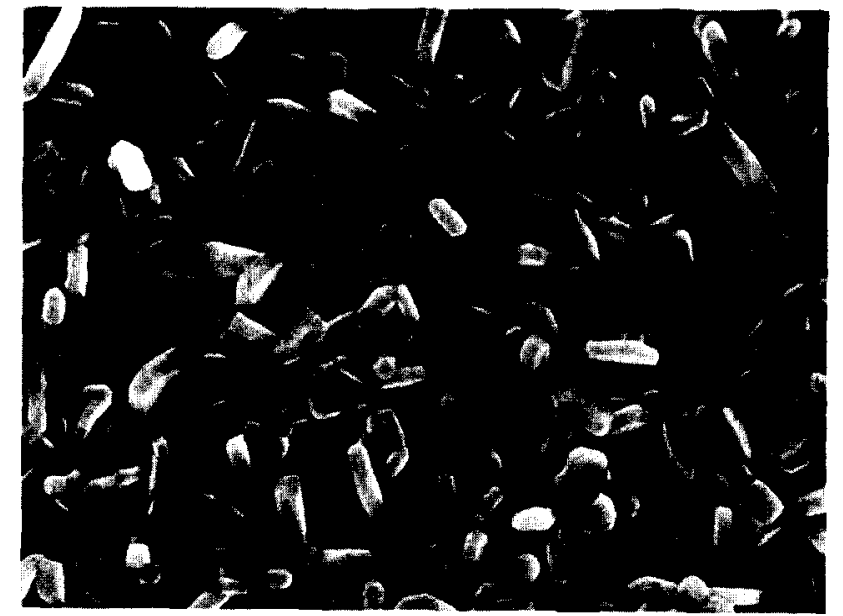

(a)

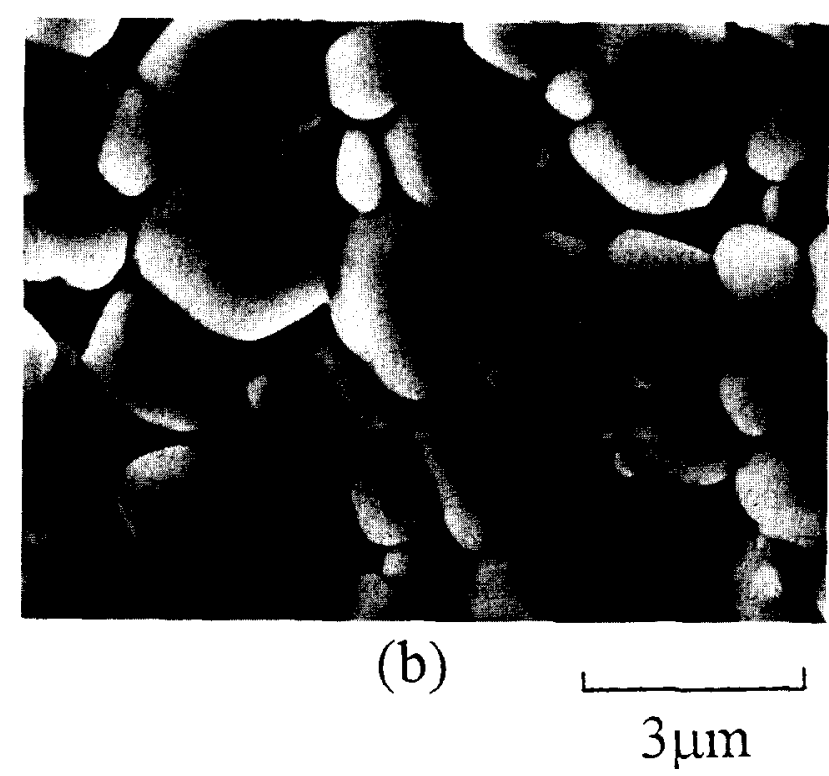

Fig. 10. Scanning electron micrographs of (a) form $2-\mathrm{Fe}_{2} \mathrm{WO}_{6}$ calcined at $950^{\circ} \mathrm{C}$ for $48 \mathrm{~h}$, and (b) the $870^{\circ} \mathrm{C}$-quenched specimen of the mixture of $\mathrm{PbO}$ and form $2-\mathrm{Fe}_{2} \mathrm{WO}_{6}$ obtained at $950^{\circ} \mathrm{C}$

Therefore, $\mathrm{Fe}_{2} \mathrm{WO}_{6}$ with a large grain-size induces $\mathrm{Pb}\left(\mathrm{Fe}_{2 / 3} \mathrm{~W}_{1 / 3}\right) \mathrm{O}_{3}$ to grow to a large grain-size.

\section{Comparison with conventional solid-state reaction}

In the conventional solid-state reaction, $\mathrm{PbO}$, $\mathrm{Fe}_{2} \mathrm{O}_{3}$ and $\mathrm{WO}_{3}$ are used as starting materials. Lead tungstates $\mathrm{PbWO}_{4}$ and $\mathrm{Pb}_{2} \mathrm{WO}_{5}$ are very easily formed during reaction. ${ }^{5}$ In the two-stage solidstate reaction, tungsten species react with $\mathrm{Fe}_{2} \mathrm{O}_{3}$ and are bound in $\mathrm{Fe}_{2} \mathrm{WO}_{6}$, therefore, no lead tungstates can be formed. The absence of lead tungstates eliminates the formation of other intermediate compounds derived from them. As a result, no $690^{\circ} \mathrm{C}$ liquid phase can be generated in the new process. The absence of the liquid phase causes pyrochlore phase to be formed as a 
powder-shape (see Figs 8(c) and 9(c)) instead of a facet-shape. ${ }^{5}$ Furthermore, the formation temperature of pyrochlore phase is reduced from 650 to $400^{\circ} \mathrm{C}$. This is attributed to the decrease in the number of intermediate compounds as well as to the simplification of the reaction process.

In conventional solid-state reaction, insufficient mixing will result in inhomogeneous distribution of $\mathrm{Fe}$ species in mixed materials. ${ }^{12}$ This inhomogeneity results in the formation of the $860^{\circ} \mathrm{C}$ liquid phase and the formation of parasite $\mathrm{Pb}_{2} \mathrm{WO}_{5}$ with $\mathrm{Pb}\left(\mathrm{Fe}_{2 / 3} \mathrm{~W}_{1 / 3}\right) \mathrm{O}_{3}{ }^{6}$ In the two-stage solid-state reaction, the mixing efficiency can be enhanced because of the decrease in the number of mixed materials. This enhancement will solve the problem in distributing $\mathrm{Fe}$ species. Consequently, the high temperature liquid phase is not formed, and pure perovskite compound can be successfully obtained.

\section{CONCLUSIONS}

A new two-stage solid-state reaction was developed for fabricating pure perovskite $\mathrm{Pb}\left(\mathrm{Fe}_{2 / 3} \mathrm{~W}_{1 / 3}\right) \mathrm{O}_{3}$ ceramics. $\mathrm{Fe}_{2} \mathrm{WO}_{6}$ was formulated at the first stage, followed by the second reaction with a stoichiometric amount of $\mathrm{PbO}$. Compared with conventional solid state reaction, this process significantly simplified the reaction mechanism and suppressed the formation of lead tungstates and liquid phases. Pyrochlore phase was formed as the only intermediate compound at low temperatures. The conversion of pyrochlore phase to $\mathrm{Pb}\left(\mathrm{Fe}_{2 / 3} \mathrm{~W}_{1 / 3}\right) \mathrm{O}_{3}$ accelerated at around $710^{\circ} \mathrm{C}$, accompanied by an endothermic reaction. At $840^{\circ} \mathrm{C}$, pure $\mathrm{Pb}\left(\mathrm{Fe}_{2 / 3} \mathrm{~W}_{1 / 3}\right) \mathrm{O}_{3}$ perovskite was yielded. The crystal structure of $\mathrm{Fe}_{2} \mathrm{WO}_{6}$ did not significantly affect the formation process; however, the grain size of $\mathrm{Fe}_{2} \mathrm{WO}_{6}$ directly influenced that of $\mathrm{Pb}\left(\mathrm{Fe}_{2 / 3} \mathrm{~W}_{1 / 3}\right) \mathrm{O}_{3}$. Through controlling the grain size of $\mathrm{Fe}_{2} \mathrm{WO}_{6}, \mathrm{~Pb}\left(\mathrm{Fe}_{2 / 3} \mathrm{~W}_{1 / 3}\right) \mathrm{O}_{3}$ with a submicron microstructure was yielded.

\section{ACKNOWLEDGEMENT}

The authors gratefully acknowledge the financial assistance by the National Science Council, Taiwan, under Grant NSC 82-0405-E002-399.

\section{REFERENCES}

1. YONEZAWA, M., Low-firing multilayer capacitor materials. Amer. Ceram. Soc. Bull., 62 (1983) 1375-83.

2. AGRANOVSKAYA, A. I., Physical-chemical investigation of the formation of complex ferroelectrics with the perovskite structure. Bull. Acad. Sci. USSR Phys. Ser., 24 (1960) 1271-7.

3. YONEZAWA, M. \& OHNO, T., Perovskite formation processes and properties of the system $\mathrm{Pb}\left(\mathrm{Fe}_{2 / 3} \mathrm{~W}_{1 / 3}\right) \mathrm{O}_{3}$ $\mathrm{Pb}\left(\mathrm{Fe}_{1 / 2} \mathrm{~W}_{1 / 2}\right) \mathrm{O}_{3}$. Jpn-US Study Semin. Dielectr. Piezoelectr. Ceram., T-8 (1982) 1-4.

4. KASSARJIAN, M. P., NEWNHAM, R. E. \& BIBBERS, J. V., Sequence of reaction during calcining of a lead-iron niobate dielectric ceramic. Amer. Ceram. Soc. Bull., 64 (1985) 1108-11.

5. LU, C. H., SHINOZAKI, K., MIZUTANI, N. \& KATO, M., Liquid-phase formation in reaction process of $3 \mathrm{PbO} \cdot \mathrm{Fe}_{2} \mathrm{O}_{3} \cdot \mathrm{WO}_{3}$. J. Ceram. Soc. Jpn. Int. Ed., 97 (1989) 115-20.

6. MIZUTANI, N., LU, C. H., SHINOZAKI, K. \& KATO, M., Formation of a high-temperature liquid phase during the sintering of $\mathrm{Pb}\left(\mathrm{Fe}_{2 / 3} \mathrm{~W}_{1 / 3}\right) \mathrm{O}_{3}$. J. Amer. Ceram. Soc., 73 (1990) 1214-20.

7. LU, C. H., SHINOZAKI, K. \& MIZUTANI, N., Precipitation synthesis and formation process of ferroelectric $\mathrm{Pb}\left(\mathrm{Fe}_{2 / 3} \mathrm{~W}_{1 / 3}\right) \mathrm{O}_{3}$. J. Ceram. Soc. Jpn, 98 (1990) 781-5.

8. LU, C. H., SHINOZAKI, K. \& MIZUTANI, N., Formation process and microstructural evolution of sol-gel derived lead iron tungstate ceramics. J. Amer. Ceram. Soc., 75 (1992) 1303-6.

9. SWARTZ, S. L. \& SHROUT, T. R., Dielectric properties of pyrochlore lead magnesium niobate. Mater. Res. Bull., 17 (1982) 1245-50.

10. WALCZAK, J., RYCHIOWSKA-HIMMEL, I. \& TABERO, P., Iron (III) tungstate and its modifications. J. Mater. Sci., 27 (1992) 3680-4.

11. WALCZAK, J. \& RYCHIOWSKA-HIMMEL, I., Phase equilibrium in the system $\mathrm{Fe}_{2} \mathrm{O}_{3}-\mathrm{WO}_{3}$ and $\mathrm{FeVO}_{4}-\mathrm{WO}_{3}$. Thermochim. Acta, 221 (1993) 115-21.

12. LU, C. H., Compositional effect on the liquid phase formation in the lead iron tungstate ceramics. J. Amer. Ceram. Soc., 77 (1994) 2529-35. 